\title{
HUKUM PENGADAAN BARANG (GOVERNMENT PROCUREMENT) DAN PEMBANGUNAN EKONOMI
}

\section{Ade Maman Suherman ${ }^{1}$}

\section{Abstrak}

Law concerning government procurement needs more an economic thought and inject it to all regulation in term of the achieving economic goals. Government procurement as a strategic issue either in international law or national law perspective. In entire developed countries, government procurement is truly dedicated to create such economic growth and to promote the welfare of state. As a comparative reference, in European countries, government procurement is regulated under regional directives and which is as an integral Part of trade and industrial policies. By regulating a comprehensive government procurement therefore, public budget can be saved through a competitive and efficient procurement, furthermore public spending can be allocated properly in term of creating an economic growth for the whole people of nation. Due to that fact, Indonesian legal policy in government procurement can take some lesson learned from several European Countries.

Kata kunci: analisa ekonomi, pengadaan barang, pembangunan ekonomi

\section{Pendahuluan}

Pengadaan barang dan jasa pernerintah mempunyai arti penting dalam pembangunan ekonomi suatu negara, namun kenyataannya di Indonesia terjadi sebaliknya, yakni pengadaan barang dan jasa merupakan lahan subur terjadinya penyimpangan baik yang dilakukan oleh aparatur negara maupun pelaku usaha. Dari segi persaingan usaha dan keuangan negara, pengadaan barang dan jasa pemerintah merupakan sektor yang penting dengan argumentasi sebagai berikut: Pertama; pengadaan memiliki arti strategic dalam proteksi dan preferensi bagi pelaku usaha dalam negeri. ${ }^{2} \mathrm{Hal}$ ini dapat

1 Dosen Fakultas Hukum Universitas Jenderal Soedirman, Purwokerto. Alamat korespondensi: ademamans@yahoo.com.

${ }^{2}$ World Trade Organization Government Procurement: The Plurilateral Agreement Overview of the Agreement of Government Procurement, 2005. 
dilihat dari besaran alokasi anggaran pengadaan barang/jasa pemerintahan yang mencapai persentase signifikan dari Anggaran Pendapatan dan Belanja Negara (APBN). Setiap tahun, sektor pengadaan membelanjakan dana yang cukup besar. Anggaran untuk sektor ini dalam APBN tahun anggaran 2001, tidak kurang dari Rp.66,57 triliun atau ( $20 \%$ dari APBN), tahun 2002 sekitar Rp. 78,15 Triliun ( $23 \%$ dari APBN), dibelanjakan melalui proses pengadaan. Nilai tersebut belum termasuk belanja oleh Badan Usaha Milik Negara/Badan Usaha Milik Daerah (BUMN/BUMD) maupun Anggaran Pendapatan dan Belanja Daerah (APED). ${ }^{3}$ Belanja Pemerintah tahun 2005 mencapai 97 triliun ( $25 \%$ dari APBN). ${ }^{4}$ Sementara itu, Rancangan APBN 2007, pendapatan negara diprediksikan sebesar 693 triliun rupiah dan belanja negara mencapai 726, 3 triliun rupiah. ${ }^{5}$ Kedua; pengadaan merupakan sektor signifikan dalam upaya pertumbuhan ekonomi. ${ }^{6}$ Ketiga , sistem pengadaan yang mampu menerapkan prinsip-prinsip tata pemerintahan yang baik akan mendorong efesiensi dan efektifitas belanja publik sekaligus tata prilaku tiga pilar (pemerintah, swasta dan masyarakat) penyelenggaraan good governance. ' Dengan kata lain, pengadaan merupakan kegiatan strategic berkenaan dengan jumlah anggaran belanja negara dan kebijakan ekonomi, dan pilar terciptanya good governance. ${ }^{8}$

${ }^{3}$ Latar Belakang Kebijakan dikeluarkannya Kepres No 80 Tahun 2003, hal. I.

${ }^{4}$ Dirjen Perbendaharaan Depkeu RI, 2006, Laporan Sementara Realisasi APBN Tahun Anggaran 2005, Periode 1 Januari 2005 sampai dengan 30 Desember 2005.

5 Iman Sugema, INDEF "Anggaran tidak memberi ruang untuk menstimulasi pertumbuhan ekonomi". Padahal, peran pemerintah dinilai penting di tengah kelesuan dunia usaha. Ini tecermin dari rendahnya penerimaan negara yang hanya 38,9 persen dan belanja negara 38 persen hingga semester 12006 .

${ }^{6}$ Latar Belakang Kebijakan dikeluarkannya Kepres No 80 Tahun 2003, Kontribusi terhadap pertumbuhan ekonomi berkisar $0,6 \%$ pada tahun 2001 (Pertumbuhan ekonomi tahun 2001 sebesar 3,44\%), pada Tahun 2002 sebesar 0,7\%, dengan angka pertumbuhan ekonomi $3,66 \%$.

${ }^{7}$ Ibid., hal. 1.

${ }^{8}$ Kepres 80 Tahun 2003 yang telah diubah menjadi Perpres RI no 8 Tahun 2006.Ruang lingkup pengadaan barang/jasa ini meliputi: pertama Pemborongan, kedua pengadaan jasa Pemborongan dan ketiga adalah pengadaan jasa lainnya. Ruang-lingkup pengadaan barang meliputi pengadaan berbagai bentuk barang/jasa baik barang/jasa yang sudah berwujud maupun barang/jasa yang masih dalam keadaan terurai, yang meliputi bahan baku, barang/jasa setengah jadi dan barang/jasa jadi. Sedangkan "pengadaan jasa pemborongan" adalah: "rangkaian kegiatan untuk mencapai kesepakatan harga dan kesepakatan lainnya dalam rangka memperoleh layanan jasa 
Berdasarkan hal tersebut diatas, bagaimana pendekatan ekonomi terhadap hukum pengadaan barang dan jasa pernerintah yang harus berdasarkan persaingan sehat, transparan dan nondiskriminatif.

\section{Pembahasan}

Menurut Posner, pendekatan ekonomi terhadap hukum selalu diidentikan dengan pembahasan hukum antitrust, hukum pajak, hukum korporasi dan regulasi kepentingan publik. Bahkan lebih jauh is menjelaskan bahwa pendekatan ekonomi terhadap hukum meliputi pembahasan bidang hukum yang berhubungan dengan masalah tort, kontrak, restitusi, properti, praktik penjatuhan hukuman, prosedur perdata, pidana dan administratif, masalah legislasi, penegakkan hukum dan administrasi pengadilan bahkan sampai pads level konstitusi, hukum keluarga dan jurisprudensi. ${ }^{9}$

Substansi teori pendekatan ekonomi secara garis besar dapat digambarkan sebagai berikut:

Law and economic can be defined as the application of economic theory (primarily micro economics and their basic concept of welfare economics) to the examine the formation structure, processes, and economic impact of law and legal institution. $^{10}$

Pendekatan ekonomi terhadap hukum diakui telah banyak dikritik oleh sejumlah pakar, berkaitan dengan apakah efisiensi merupakan isu hukum dan tidak bertentangan dengan keadilan. Perdebatan selalu terjadi, dan itulah menunjukan daya tariknya yang unik sehingga selalu menjadi objek kajian

pemborongan, Bandingkan dengan ruang lingkup pemborongan menurut UNCITRAL, jasa pemborongan konstruksi meliputi: "jasa pemborongan konstruksi" adalah semua layanan pekerjaan yang bersangkutan dengan pembangunan, rekonstruksi, pemusnahan bangunan, perbaikan atau renovasi gedung, bangunan atau pekerjaan persiapan lokasi, ekskavasi, pemancangan, pembangunan instalasi peralatan atau material, dekorasi dan finishing (sentuhan akhir) berikut jasa-jasa insidentil dalam pembangunan seperti pengeboran, pemetaan, pemotretan satelit, penyelidikan seismic dan jasa-jasa sejenis yang diberikan sehubungan dengan kontrak pengadaan, bilamana nilai-nilai jasa tersebut tidak melebihi nilai pembangunannya sendiri.

9 Richard A. Posner, "Economic Analysis of Law", 5th Edition, (Aspen Law \& Business, 1997), hal. 25.

${ }^{10}$ Nicolas Mercuro and Steven G. Medema, "Economic and The Law, From Postner to Post Modernism". (Priceton University Press, 1999), hal. 1. 
kontemporer. Menurut Harold J. Berman bahwa konflik antara keadilan sebagai efisiensi (justice as efficiency) dan keadilan sebagai fairness (justice as efficiency dan justice as fairness) sebagai perdebatan kontemporer antara pandangan politik dari hukum dengan teori moral (fairness) is menyatakan perdebatan tersebut sebagai "the contemporary battle between a political view of law (efficiency) and a moral theory (fairness)". ${ }^{11}$

Dalam suatu ekspresi personal, Robert Cooter memberikan gambaran yang tepat mengenai pertemuan dua tradisi ilmu pengetahuan dalam artikelnya sebagai berikut:

As a boy I camped on a sand bar off the Carolina coast at the coinfluence of the two oceans currents that made the waters rough but fertil. As an economist in a law school, I am the confluence of two intellectual traditions. The stark one is quantitative, the other is verbal, on is empirical, the other is hermeneutical, one aspires to scientific, the other aspires to be just. Given these differences, discourse between economists and lawyers in inevitably rough, but it has also been fertile in recent years. $^{12}$

Apakah keadilan dapat dijumpai dalam efisiensi atau kejujuran (efficiency atau fairness), ${ }^{13}$ itulah pertanyaan mendasar dalam disiplin hukum kontemporer. Kedua pandangan mempunyai akar sejarah yang berbeda yaitu justice as fairness mempunyai akar sejarah dari teori hukum alam, sementara persepsi justice as efficiency berakar dari legal positivism, ${ }^{14}$ khususnya teori utilitarian yang mempunyai anggapan bahwa hukum dan kebijakan sosial

11 Harold J. Berman, Woodruff, Emory University School of Law, dalam Washington Law Review, 2005.hal. 70.

12 Robert Cooter, Herman Selvin, University of California, Berkeley, $\mathrm{CA}$, The Influence of Justice and Efficiency in The Economic Analysis of Law, Desember, 2003, hal. 2.

13 Nicholas Mercuro \& Steven G. Medema, "Economics and the Law: From Posner to Post-Modernism", 1997, hal. 60, lihat juga James Boyd White, Economics and Law: Two Cultures in Tension, 54 Tennesse. Law Review, 1987, hal. 161, 198.

${ }^{14}$ Aliran Positifisme diklasifikasikan kedalam beberapa aliran yaitu aliran positifisme klasik, positivisme utilitarian, positifisme ajaran hukum murni dan neo positifisme. Neo positifisme dipelopori sejumlah pakar yaitu Ronald Zworkin, John Rawls, H.L.A. Hart dan Richard A. Posner. 
sebagai instrumen atau alat dan mempunyai hal-hal yang berkonsekuensi. ${ }^{15}$ Pada umumnya orang beranggapan bahwa antara efisiensi dan keadilan suatu yang divergent atau selalu berbeda, tetapi sesungguhnya kedua hal tersebut dapat diunifikasi dan diintegrasikan antara konsep fairness dengan konsep efisiensi. Menurut Posner, dijelaskan bahwa:

A second meaning of justice, perhaps the most common, is-efficiency. There is more to notions of justice than a concern for efficiency. The Economics of Justice, he wrote: $V$ have tried to develop a moral theory that... holds that the criterion for judging whether acts and institutions are just or good is whether they maximize the wealth of society. ${ }^{16}$

Pendekatan ekonomi terhadap hukum tidak sekedar berbicara masalah efisiensi, namun juga memprediksi efek dari kebijakan-kebijakan terhadap suatu nilai yang penting yaitu "distribusi". Bahkan para ekonom mengklaim sebagai profesi yang paling memahami bagaimana hukum mempunyai akibat terhadap distribusi pendapatan dan kemakmuran antar kelas dan kelompok dalam masyarakat. Pada dasarnya hukum dari suatu negara dan ilmu sosial bagaimana untuk memproduksi dan mendistribusikan kemakmuran, keadilan dalam distribusi kekayaan antar semua kelas dalam masyarakat merupakan pokok pembahasan dari keadilan distributif. Hal ini sejak lama telah menjadi topik utama sejak Republik Plato dimana keadilan sebagai topik utama dari filsafat politik dan filsafat etika. Mengkombinasikan kesejahteraan individu dan kesejahteraan sosial adalah cara para ekonom untuk menjelaskan tugasnya dalam merekonsiliasi kepentingan yang bertentangan antara kelas dan kelompok kepentingan. Teori-teori kesejahteraan sosial dipandang oleh para ahli filsafat sebagai satu keluarga diantara tradisi-tradisi yang bersaing dimana mengajukan suatu solusi terhadap masalah keadilan distributif. ${ }^{17}$

Sebagaimana diungkapkan oleh Cooter, terdapat satu ilustrasi yang tepat dimana antara keadilan dan efisiensi harus ada secara bersamaan dan saling melengkapi, yaitu disuatu padang pasir terdapat dua oase yang relatif berjauhan, satu oase memiliki cukup ice cream dan oase yang satunya tidak

${ }^{15}$ Michael I. Swygert dan Katherin Earle Yanes, A Unified Theory of Justice: The Integration Of Fairness Into Efficiency, Washington Law Review, April, 1998, hal. I.

${ }^{16}$ Richard A. Posner, "The Economics of Justice", (Harvard University Press, 1981), hal. 26.

${ }^{17}$ Robert Cooter, Op. Cit., hal. 18. 
memiliki sama sekali. Untuk menegakkan keadilan sosial dan mengapresiasi efisiensi, maka oase pertama harus membagi ice cream dengan oase yang kedua. Dalam merespon keadaan tersebut, oase pertama merespon dan mengisi mangkok besar dan mengirimnya seorang pemuda yang mampu berlari menyebrangi padang pasir membawa semangkuk ice cream menuju oase kedua. Panas terik matahari gurun melelehkan ice cream, maka oase pertama mengirim banyak ice cream lebih banyak daripada yang diterima oleh oase kedua. Dengan demikian melelehnya ice cream ditengah perjalanan sebagai ongkos dari distribusi. Dengan demikian bagaimana jalan keluar agar seberapa banyak ice cream yang harus dikirim ke oase kedua dan dapat diterima secara efisien, maka pertama harus memilih pemuda yang bisa lari lebih cepat dari yang pertama, kedua memilih pemuda yang jujur dan dipastikan tidak memakan ice cream tersebut ditengah jalan.

Dengan contoh diatas, maka setidaknya dapat meyakinkan bahwa menganalisis isu liberalisasi, prinsip-prinsip dan tujuan pengadaan barang dan jasa pemerintah jelas mutlak dibutuhkan efisiensi. Berdasarkan esensi dari pendekatan ekonomi terhadap hukum, pengadaan barang dan jasa berada dalam ranch yang tepat untuk dianalisis menggunakan teori ini dengan alasan bahwa liberalisasi pengadaan barang dan jasa adalah merupakan salah satu rejim perdagangan internasional yang didasarkan pada teori-teori ekonomi yang menghendaki adanya efisiensi dan distribusi kesejahteraan sosial antara kelas dan kelompok dalam masyarakat.

Disamping itu, persaingan usaha melalui kompetisi antara pelaku usaha baik pelaku usaha asing maupun pelaku usaha domestik harus menggunakan indikator ekonomi sehingga tujuan secara ekonomi tercapai dan terhindar dari inefisiensi serta distorsi pasar. Dengan demikian, hak-hak warga negara sebagai pembayar pajak akan lebih terjamin dengan memilih para bidder yang jujur dan mempunyai kapabilitas yang kompetitif.

Analisis ekonomi adalah merupakan persoalan menentukan pilihan dalam kondisi kelangkaan. Kelangkaan ekonomi diasumsikan bahwa individu atau masyarakat selalu berusaha memakasimalkan apa yang diinginkan dengan menggunakan sumberdaya sebaik mungkin. Dalam melakukan pendekatan ekonomi terhadap hukum, dikenal terdapat dua model yaitu pertama analisis positif dari hukum dan kedua analisis normatif. Analisis yang pertama akan menjawab bagaimana bila suatu legal policy diberlakukan, prediksi-prediksi apa yang dapat dibuat dan mempunyai akibat ekonomi. Dengan kata lain individu atau setiap orang, kelompok maupun negara dalam konteks yang lebih bersar akan merespon bagaimana adanya insentif dan disinsentif dari kebijakan hukum yang diberlakukan. Sedangkan 
analisis yang kedua dapat dikatakan sebagai pendekatan konvensional yang dikenal dengan welfare economics approach. Kebijakan hukum dan pembaharuan-pembaharuan yang dilakukan akan berpengaruh terhadap individu-individu, kelompok maupun organisasi untuk pencapaian suatu kepentingan didasarkan pada konsep efisiensi.

Konsep efisiensi dalam ekonomi telah diperkenalkan oleh dua ekonom terkemuka dengan teorinya Pareto efficiency dan Kaldor-Hicks efficiency. Pareto efficiency menekankan pembahasannya pada apakah kebijakan atau pembaharuan hukum akan menimbulkan keadaan yang lebih baik dengan tidak mengakibatkan pihak lain bertambah buruk (worsed off). Sedangkan konsep Kaldor-Hicks efficiency membahas apakah kebijakan atau pembaharuan telah menghasilkan keuntungan yang cukup bagi mereka yang mengalami perubahan itu, sehingga secara hipotetis, dapat memberikan kompensasi kepada mereka yang dirugikan akibat kebijakan perubahan hukum tersebut. Pendekatan ekonomi yang terakhir adalah bagaimana melihat suatu kebijakan hukum ditinjau dari sudut biaya dan keuntungan yang diperoleh. ${ }^{19}$

Sebagai perbandingan dan bahan rejukan, betapa pentingnya masalah pengadaan barang daan jasa pemerintah, perlu menelaah perkembangan dan pengaturannya di sejumlah Negara Eropa dimana iklim kompetisi sudah berjalan dengan baik. Hal ini tentunnya tidak terlepas dari dukungan dan reliabilitas aturan yang terkait dengan pengadaan barang dan jasa pemerintah.

Dalam konteks kerjasama regional atau Regional Trade Agreement (RTA) pengadaan barang dan jasa pemerintah telah menjadi fenomena yang semakin menguat berhadapan dengan rejim WTO. The multilateral trade system has witnessed phenomenal growth in the number, coverage, and scope of RTAs. ${ }^{20}$ Keuntungan dari sistem kerjasama regional khususnya bagi Uni Eropa dapat dijelaskan sebagai berikut: ${ }^{21}$

${ }^{19}$ Michael J. Trebilcock, Law and Economic", The Dalhouse Law Journal, Vol.16, No. 2, Fall, 1993, hal. 361-363.

${ }^{20}$ Thomas Cottier, "The Challenge of Regionalism and Preferential Relations in World Trade Law and Policy", I Eur. Foreign Aff. Rev. 149, 149 (1996), see also World Bank, Trade Blocs 1 (2000), ("The growth of regional trading blocs ... is one of the major international relations developments of recent years").

${ }^{21}$ Colin B. Picker, Regional Trade Agreements Of Article XXIV V. The WTO: A Proposal For Reform To Counter. This Institutional Threat University of Pennsylvania Journal of International Economic Law Summer 2005, hal. 267. 
While it has been asserted that the present "fever" of activity in developing regional arrangements is due to globalization, ${ }^{22}$ there have been other periods of regionalism before this present burst of activity, ${ }^{23}$ albeit none so frenetic as the period since the birth of the WTO. ${ }^{24}$ There are many reasons for this growth, though in the early period of the multilateral trade system-the post-war years-much of the growth in RTAs was related to continuing colonial associations. ${ }^{25}$ Additionally, in those post-war years, RTA formation was encouraged as another mechanism to help increase security in Europe. ${ }^{26}$

${ }^{22}$ Carlos Alberto Primo Braga, "Regional Trade Organizations: Strengthening or Weakening Global Trade", Remarks Before the American Society of International Law (Apr. 7, 1994), in 88 Am. Soc'y Int'l L. Proc. 309, 310 (1994).

${ }^{23}$ Bhagwati, Writings, supra note 10, at 167-172, (Discussing the Regionalisms of the 1960s and 1980s).

${ }^{24}$ Carlos Alberto, Op. Cit., hal. 90. Lebih dari setengah dari RTAs. telah dinegosiasikan dalam sepuluh tahun terakhir. WTO, Regional Trade Agreements, <http://www.wto.org/english/tratop_e/region_e/region_ e.htm>, last visited April. 3, 2005. It has also been suggested that perhaps a major reason for so many countries, especially developing countries, taking part in RTAs.4 is the abandonment of the trade policy of "import substitution" in the same period. Frankel, supra note 6, at 7-10; see also Amy Porges, Regional Trade Organizations: Strengthening or Weakening Global Trade?, Remarks Before the American Society of International Law (Apr. 7, 1994), in 88 Am. Soc'y Int'l L. Proc. 312, 31212 (1994) (Banyak alasan dikemukakan oleh negara berkembang bahwa benar-benar mereka memperoleh keuntungan dari RTAs. World Bank, Trade Blocs, supra note 14, at 2 (Providing that import substitution was the basis for the formation of trading blocs in the 1960 s and 1970 s but that recently regional agreements are more outward looking).

25 Kym Anderson \& Hege Norheim, "History, Geography and Regional Economic Integration, in Regional Integration and the Global Trading System 19", 39-41 (Kym Anderson \& Richard Blackhurst, Eds., 1993), (Describing British and French RTAs. 4 With Their Former Colonies).

${ }^{26}$ Mathis, supra note 10, at 28 (reporting Roosevelt's declaration that entering into an RTA after World War II would avoid "replay of the Versailles Treaty" between "potential victors and the vanquished"). 
Ketika kecenderungan akan perhatian terhadap, RTA semakin meningkat, namun sebaliknya antusiasme terhadap WTO semakin berkurang. Sebagaimana dijelaskan oleh Collin B.Pecker, bahwa:

The erosion of enthusiasm for the WTO may also be caused by an excessive focus on RTAs by local policy makers, academics, and government civil servants busy concentrating on putting RTAs into operation. Consequently, those policy makers will have less enthusiasm for the WTO as they are fixated on the RTA. For example, in the EU, there is considerably more knowledge and involvement (enthusiasm) with EU law than that of the WTO--despite the centrality of the WTO to the EU and convergence in much of the substantive parts. ${ }^{27}$

Salah satu organisasi kerjasama regional yang paling established adalah Uni Eropa yang telah menempatkan pengadaan barang dan jasa sebagai agenda penting dan tidak terpisahkan dari kebijakan industri dan perdagangan. Berikut ini gambaran singkat mengenai pengeluaran anggaran negara anggota di bidang pengadaan barang dan jasa pemerintah:

${ }^{27}$ J.H.H. Weiler, "Cain and Abel-Convergence and Divergence in International Trade Law", in The EU, the WTO and the NAFTA (J.H.H. Weiler ed., 2000). But, note that the World Bank Report asserts that neither the EU nor the United States seem to be less disposed toward multilateral negotiations because of their RTAs or the RTAs of other. World Bank, Global Economic Perspectives, supra note 4, at 134. 
Tabel 1 Nilai Pengadaan Barang/Jasa di Eropa ${ }^{28}$

\begin{tabular}{|c|c|c|c|}
\hline Negara & $\begin{array}{c}\text { Total Public } \\
\text { Procurement } \\
\text { (Juta ECU) }\end{array}$ & $\begin{array}{c}\text { Suplies and Service } \\
\text { Proc (Juta Eu) }\end{array}$ & $\begin{array}{c}\text { Construction Proc. } \\
\text { (Juta Eu) }\end{array}$ \\
\hline Inggris & 65,206 & 51,904 & 13,302 \\
Belgic & 26,938 & 11,557 & 9,326 \\
Denmark & 21,482 & 9,216 & 6,493 \\
Jerman & 176,927 & 51,310 & 24,891 \\
Italia & 142,496 & 31,079 & 19,359 \\
Luxembourg & 1,253 & 538 & 124 \\
Portugal & 7,042 & 1,536 & 896 \\
Spanyol & 52,866 & 11,536 & 9,423 \\
Irlandia & 5,936 & 3,150 & 958 \\
Prancis & 69,897 & 45,533 & 24,464 \\
Belanda & 25,412 & 8,200 & 7,171 \\
Yunani & 6,531 & 3,380 & 1,027 \\
\hline
\end{tabular}

Sumber: Commission of the European Communities, The cost of Non - Europe in Public. Sector Procurement, 1990: National Westminster Bank, Economic and Financial Outlooks, 1994; OECD, Econmic Outlook, Desember 1994.

Di Inggris struktur Public Procurement dapat diklasifikasikan kedalam lima macam badan peserta kontrak (contracting entities) yaitu: pemerintah pusat, yang terbagi kedalam berbagai departemen dan agen, termasuk kementrian pertahanan (Ministry of Defence) dalam kapasitasnya dalam pelelangan terhadap supply non military purposes, pemerintah lokal yang terbagi kedalam county, distrik dan borough council. Sementara untuk Dewan Kesehatan Nasional (National Health Council), telekomunikasi, air bersih dan sektor transportasi sudah diprivatisasi. Suatu hal menarik dalam sistem procurement di Inggris terdapat adanya lembaga "Quangos" (Quasi - autonomous non

${ }^{28}$ Commission of the European Communities, "The cost of NonEurope in Public Sector Procurement, 1990: National Westminster Bank", Economic and Financial Outlooks, 1994;OECD, Economic Outlook, Desember 1994. 
govermental organizations) yang tunduk pads hukum publik procurement. Quangos mengatur procurement yang dilaksanakan oleh universitas dan institusi pendidikan tinggi lainnya. Sebaran nilai public procuremen sebanyak $27 \%$ oleh pemerintah pusat, local authorities sebesar $25 \%$, kementrian pertahanan $26 \%$, bidang public uitility $15 \%$ dan quangos sebesar $7 \%{ }^{29}$

Sementara itu, Prancis memilik struktur yang lebih sederhana yaitu tiga lembaga atau contracting entities yaitu: (1) pemerintah pusat dengan berbagai departemen dan lembaga termasuk kementrian pertahanan untuk tujuan proyek sipil (civilian purposes), (2) Pemerintahan Lokal, dan (3) Korporasi Publik yang menaungi bidang telekomunikasi, air, energi dan sektor transportasi. Nilai sebaran proyek antara pemerintah pusat dengan pemerintah daerah relatif sama yaitu $28 \%$ dan $25 \%$, sedangkan untuk public utilities adalah sisanya yaitu $47 \%$ dari total public procurement. ${ }^{30}$

Berikut ini suatu kasus yang menarik antara Inggris dan perusahaan subsidiary Prancis yaitu Harmon CFEM Facades UK Ltd v Corporate officer of the house of commons. Berdasarkan article 2 of the Remedies Directives sets out the remedies which must be provided by member states for break of the EU Procurement rules. Kasus ini merupakan perkara klasik dimana ganti rugi dapat duajukan atas pelanggaran terhadap kontrak pengadaan yang mengecewakan yang dilakukan tender dan interaksi antara hukum procurement Eropa dan hukum Common Law Inggris. Kasus ini berawal dari proyek pembangunan Portcullis House untuk akomodasi parlemen di Westminster. Perusahaan Inggris Seele Alvis dan Harmon yang sama—sama perusahaan Inggris, namun Harmon adalah merupakan subsidiary Perusahaan Prancis. Harmon dirugikan dan diskriminasi dari proses tender yang dilakukan oleh otoritas Inggris. Tuntutan yang diajukan adalah tender cost, lost profit and to reflect PWD's conduct (agravated and exeplary damages). ${ }^{31}$ Secara bertingkat, regulasi hukum procurement di Inggris terdiri dari tiga tingkatan, yaitu level lokal, domestik dan Uni Eropa. Berikut ini domestic legislation di Inggris terdiri atas:

${ }^{29}$ Christpher Bovis, Op. Cit., hal. 13.

${ }^{30}$ Ibid.

31 Ellis D. Baker, Anthony Lavers, Remedies for Breach of EU Procurement Regulation, lebih jauh dapat dilihat pada alamat: $<$ www.whitecase.com/publication/pubsdetail.aspx >, diakses tanggal 22 Maret 2010. 
The Local government act 1999. The local government act, 2000, The local government and Housing Act 1989, which contains provision for local authority involvement in companies; The Local Authorities (goods and services) Act 1970; The Local Government Act 1972.

The Local government (contracts) At 1977; and The Health Act 1999 (partnership agreement)". ${ }^{32}$

Tabel 2 Reguliasi di Inggris dan Uni Eropa tentang Government Procurement

\begin{tabular}{|c|c|}
\hline UK Regulation & EU Directives \\
\hline $\begin{array}{l}\text { Public Work Contracts Regulation } \\
1991 \\
\qquad(5.11991 \text { No. } 2680)\end{array}$ & $\begin{array}{c}\text { Council Directives 71/305/EEC, } \\
\text { Diamandemen oleh Council } \\
\text { Directive 89/440/EEC dan Council } \\
\text { Directive } 8916651 \text { EEC }\end{array}$ \\
\hline $\begin{array}{c}\text { Public Service Contracts Regulations } \\
1993 \text { (5.1. } 1993 \text { No. } 3228)\end{array}$ & Council Directive 92/50/EEC \\
\hline $\begin{array}{l}\text { Public Supply Contracts Regulations } \\
\text { (S1. } 1995 \text { No. 201) }\end{array}$ & $\begin{array}{c}\text { European Parliament and Council } \\
\text { Directive 97/52/EC }\end{array}$ \\
\hline $\begin{array}{l}\text { Public Contracts (works, service and } \\
\text { supply) and Utilities Contracts } \\
\text { (Amendments) Regulations } 2003 \\
\text { (S.I.2003 No. 46) }\end{array}$ & Commission Directive 2001/78/EC \\
\hline
\end{tabular}

Sumber: 2003 Improvement and Development Agency, UK

Berbeda dengan Inggris dan Prancis, Belanda memiliki struktur kelembagaan yang terpusat yaitu semua public procurement ditangani oleh Rijkinkoopbureau. Lembaga tersebut sebagai intermediary antara supplier dengan lembaga pemerintah. Namun belakangan ini telah terjadi restrukturisasi dan masing-masing melakukan pelelangan secara masing-masing. ${ }^{33}$ Satu leading case di Eropa, tepatnya Belanda telah menjatuhkan denda terhadap pelanggaran regulasi

32 Tentang "Basic Guiode to Contract Procurement Law, Consultation Draft", <www.hmso.gov.uk>, diakses tanggal. 25 Juli 2003.

${ }^{33}$ Christopher Bovis, Op. Cit., hal. 14. 
procurement Eropa. Kasus tersebut adalah NMa Fines 22 Construction Companies for Cartel Agreements. ${ }^{34}$

Otoritas Persaingan Belanda The Netherlands Competition Authority (NMa) telah menjatuhkan denda terhadap 22 perusahaan konstruksi atas dugaan pelanggaran terhadap larangan kartel. Perusahaan tersebut didakwa atas perbuatan price fixing, market sharing agreements and bidrigging. Pelanggaran tersebut terjadi setelah diberlakukannya The Competition Act secara efektif berlaku pada tanggal 1 Januari 1998. Kasus ini merupakan pertama kalinya investigasi terhadap perusahaan jasa konstruksi. Terdapat lima poin penting dalam kasus tersebut dan kita dapat melihat jenis pelanggaran, perusahaan konstruksi dan berapa besarnya denda yang dikenakan.

Kasus pertama, NMa telah menjatuhkan denda terhadap 9 perusahaan konstruksi atas tuduhan bidrigging agreements dalam rangka pemeliharaan jalan di Provinsi Groningen, Friesland and Drenthe. Kasus ini melibatkan perusahaan berikut ini; Ballast Nedam Infra Noord Oost B. V. didenda sebesar EUR 240,000, Koop Tjuchem B. V.didenda sebesar EUR 677,000, Oosterhof-Holman Infra B. V. (EUR 313,000), Reef Infra B.V. (EUR 429,000), Wegenbowmaatschappu $J$ Heijmans B. $V$. (EUR 289,000), Koninklijke Wegenbouw Stevin B. V (EUR 240,000), BAMNBM Wegenbouw Noordoost B.V. (EUR 585,000) dan Vermeer Infrastructuur B. V. (EUR 327,000);

Kasus kedua, dikenal dengan "Noord-Holland Eight" atau 'Schiphol Eight' yang terlibat proses bidrigging secara berlanjut dalam proses procurement dari 15 proyek infrastructural besar di region Haarlemmermeer/Schiphol. Denda dijatuhkan kepada perusahaan berikut ini: Ballast Nedam Infra Noord West B.V. dan Ballast Nedam Infra B. V. (EUR 14,548,000 secara bersama-sama), HBG Civiel B.V. dan Hollandsche Wegenbouw Zanen B. V. (EUR 14,436,000 secara bersamasama), Vermeer Infrastructur B.V. (EUR 11,248,000), Koninklijke Wegenbouw Stevin B.V (EUR 18,429,000), NBM Noord-West B.V. (EUR 12,190,000), Wegenbouwmaatschappy J Heijmans B.V. (EUR 13,874,000), Koop Tjuchem B.V. (EUR 6,283,000) dan Ooms Avenhorn B.V. (EUR 3,604,000);

Kasus ketiga, berkenaan dengan konstruksi tracks atletik berupa pelanggaran dengan melakukan market sharing agreements terhadap

${ }^{34}$ Carnegie Endowment for International Peace, <www.matrixgroup.net.03-52a>, diakses tanggal, 19-Desember 2004. 
sejumlah lima perusahaan terpenting yang aktif dalam bidang jasa konstruksi, renovasidan perawatan synthetic athletic tracks, Atas perbuatan tersebut dikenakan denda sebagai berikut: Groenewoud Sport \& Recreatie B. V. (EUR 450, 000), Arcadis PlanRealisatie B.V (EUR 369,000), Van Gelder Cultuurtechniek B.V (EUR 67,000), Ingenieursbureau Oranjewoud B. V (EUR 1,213,000), Aannemingsbedrijf Van Lee B. V and Heijmans Sport en Groen B.V. (EUR 610, 000 jointly);

Kasus keempat, NMa menjatuhkan denda pada sebuah perusahaan karena tindakan berupa anticompetitive agreement antara Humans Beton- en Waterbouw B. V. dan Solétanche Bachy France S.A.

In relation to the permanent exchange of sensitive competitive information and the exclusion of competition in relation to civil engineering concrete work, in which special foundation techniques were applied Fines were imposed on Heijmans N. V. (EUR 50, 000) and Solétanche Bachy France S.A. (EUR 50,000). NMa investigated the relationship between Heijmans and Solétanche following a complaint filed by the municipality of Amsterdam in relation to tendering for parts of the North-South underground.

Kasus kelima, mengenai tendering agreements mengenai kasus pebangunan jalan Mokerstraat dan Aambeeldstraat di Amsterdam Utara yang proyeknya relatif kecil. NMa mengambil tindakan tehadap kasus ini atas tuduhan perjanjian terlarang (prohibited agreements) dan telah diselidiki melalui penyelidikan parlemen terhadap industri konstruksi dan NMa secara eksplisit telah menyatakan akan mengambil tindakan karena bidrigging schemes in the construction industry. Maka untuk pelanggaran ini, dijatuhkan denda sebagai berikut: Floris Aannemingsmaatschappij B.V. (EUR 14,400), Zandrema B.V. (EUR 8,900), Aannemingsbedrijf AC de Groot B. V. (EUR 2,600). Leniency was granted in this case to two companies. This resulted in a reduction of fines by $70 \%$ in the case of Aannemingsbedrijf De Groot and $25 \%$ in the case of Floris Aannemingsmaatschqpij. ${ }^{36}$

Apabila dianalisis secara kontraktual, analisis ekonomi terhadap hukum pengadaan barang dan jasa pemerintah dapat dijelaskan dalam pola hubungan keterkaitan sebagai berikut:

36 Ellis D.Baker, Anthony Lavers, Remedies for Breach of EU Procurement Regulation, <www.whitecase.com/publication/pubs-detail.aspx $>$, diakses tanggal 12 Juli 2010. 


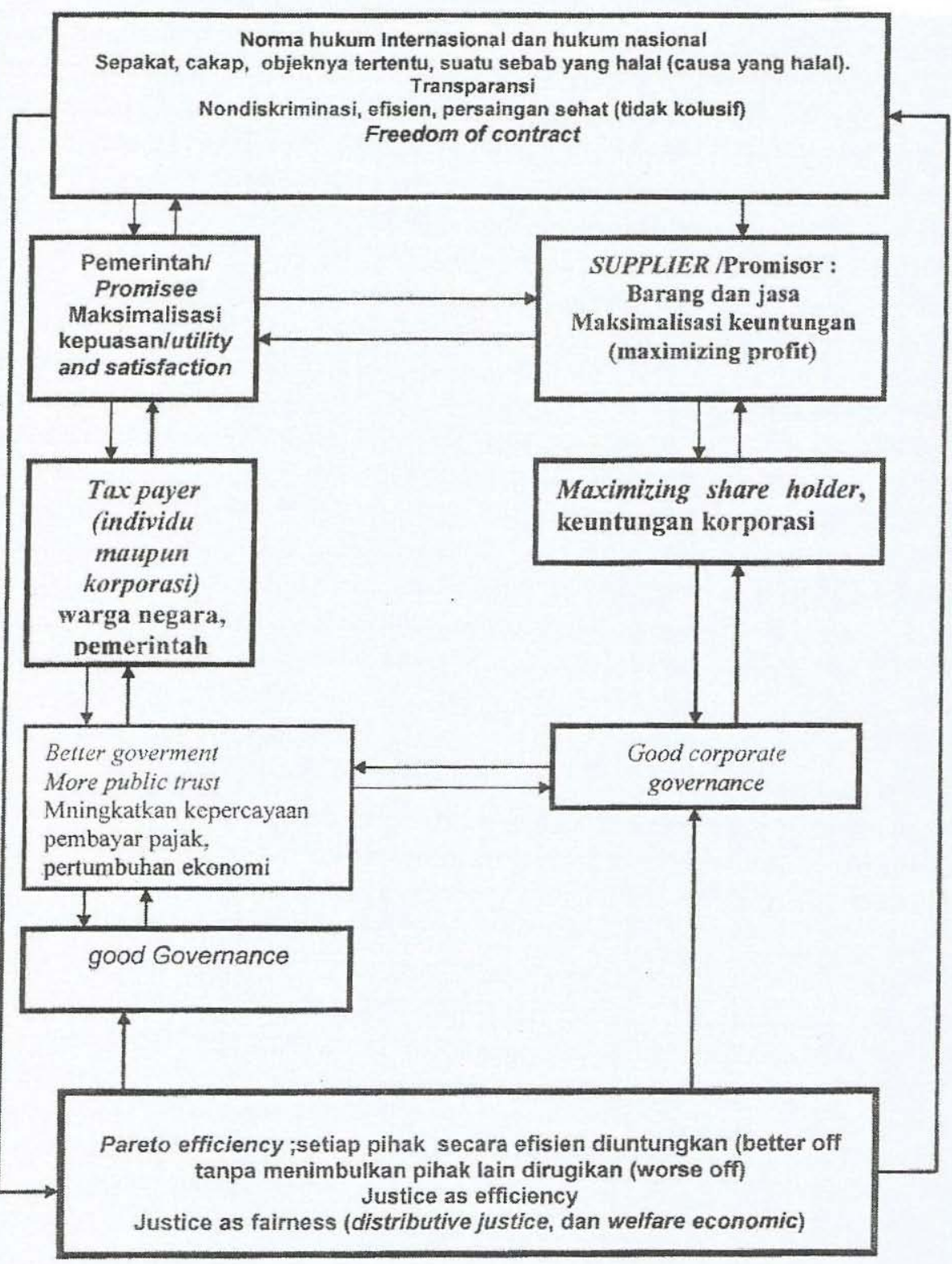

\section{Ragaan 1. Hubungan Kontraktual Pengadaan Barang dan Jasa Pemerintah dalam Pendekatan Ekonomi}

Pertama, kontrak pengadaan barang dan jasa sebagai kontrak antara pemerintah sebagai pembeli dengan penyedia barang dan jasa (an economic 
theory of contract), Selain itu harus dikondisikan bagaimana pola hubungan antara pelaku usaha asing dengan pelaku usaha domestik, maupun antar pelaku usaha domestik ketika terjadi sub-contracting, harus menciptakan kondisi yang better off atau mutual benefit bagi kedua belah pihak. Perkembangan masyarakat dari segi hukum telah merubah pola tatanan hubungan antara subjek individu maupun kelompok yang semula dikondisikan dari "status menjadi kontrak". Hal ini sebagaimana ditegaskan oleh Henry Maine bahwa: "The movement of the progresive societies has hitherto been a movement from status to contract". "Hubungan antara para pihak dalam pengadaan barang dan jasa muncul dari adanya janji (promise) yang dibuat oleh promisor dan promisee dimana janji yang disepakati harus dapat dilaksanakan (enforcability of contract). Dalam pelaksanaannya, antara kedua belah pihak harus saling diuntungkan atau menuju pada suatu keadaan lebih baik (better-off). Tanga menimbulkan salah satu pihak menjadi lebih buruk (worse off). Menurut Robert Cooter dan Thomas Ulen ditegaskan:

Enforceability of the contract apparently makes two people better off, as measured by their own desires without making anyone worse off. Whenever a chnage in the law makes someone better off without making anyone worse off, "Pareto efficiency". ${ }^{38}$

Lebih jauh bagaimana mengukur efisiensi dari suatu kontrak termasuk dalam pengadaan barang dan jasa, maka melalui pendekatan ekonomi dapat dijelaskan dengan dua kemungkinan yaitu:

[Promisor's cost of performing > promisee's benefit from performing]

$\longrightarrow$ efficient to breach;(biaya kinerja pembuat janji lebih besar daripada keuntungan penerima janji dari kinerja tersebut, maka hasilnya akan lebih efisien untuk melanggar perjanjian); sebaliknya, bila:

$\longrightarrow$ [Promisor's cost of performing < promisee's benefit from performing]

efficient to perform; (Biaya kinerja pembuat janji lebih rendah dari keuntungan yang diterima si penerima janji, maka hasilnya akan lebih efisien untuk memenuhi perjanjian).

Berdasarkan formulasi tersebut maka pihak yang menjanjikan dan pihak yang dijanjikan akan sampai pada kondisi dimana dihadapkan pada

${ }^{37}$ Henry Maine dalam Nicolas Mercuro and Steven G. Medema, Op. Cit., hal. 177.

${ }^{38}$ Ibid. 
dua kondisi kemungkinan, yaitu pertama apakah dianggap efisien untuk melanggar kontrak sebagaimana digambarkan dalam rumus pertama atau sebaliknya, akan efisien untuk memenuhi kontrak sebagaimana memenuhi rumusan kedua (efficient to perform). Apabila dikaitkan dengan efisiensi kontrak pengadaan barang dan jasa perlu diperhatikan masalah biaya sebagai elemen utama untuk menentukan apakah efisien atau tidak untuk memenuhi kontrak atau sebaliknya. Relevansi dengan pengadaan barang dan jasa tentunya berkaitan dengan bagaimana regulasi pengadaan barang dan jasa mengatur prosedur pengadaan barang dan jasa secara efisien sehingga tidak memakan biaya tinggi.

Kedua, Hal yang esensial dari pendekatan ekonomi adalah Maksimalisasi utility $^{39}$ dari barang dan jasa oleh pengguna (pemerintah, warga negara sebagai pembayar pajak) dan maksimalisasi keuntungan oleh penyedia barang dan jasa. Pengguna barang dan jasa atau konsumen baik pemerintah sebagai lembaga yang mewakili kepentingan publik harus sesuai dengan apa yang diperjanjikan dalam kontrak dan memenuhi kepuasan pengguna. Kepuasan tersebut merupakan suatu tingkatan dimana perkiraan kinerja produk (barang atau jasa) sesuai dengan harapan pengguna. ${ }^{40} \mathrm{Bagi}$ penyedia barang dan jasa tentunya akan melakukan pendekatan maksimaliasi keuntungan (the profit-maximizing firm). Masing-masing pihak baik konsumen maupun produsen atau penyedia barang dan jasa akan memaksimalkan dari kepentingannya masing-masing bahwa:

The firm is the institution in which output (product and services) is fabricated from inputs (capital, labours, land, etc.) Just we assume that consumers rationally maximize utility subject to their income constratint, we assume that firms maximizing profit subject to the constraint imposed on them by consumer demands and the technology of production. ${ }^{4 I}$

Ketiga, Cost and benefit dari suatu kebijakan yaitu liberalisasi pengadaan barang dan jasa akan menghasilkan seuatu keuntungan atau kerugian bagi pelaku usaha dalam negeri. Keempat, Bagaimana hukum pengadaan barang dan jasa pemerintah yang efisien, menguntungkan para

${ }^{39}$ Ibid., utility diartikan Happiness or satisfaction atau kebahagiaan dan kepuasan.

${ }^{40}$ Kotler \& Amstrong, "Prinsip-prinsip Pemasaran", (Jakarta: Penerbit Erlangga, 2001), hal. 13. 
pihak dan secara lugas dapat meningkatkan kesejahteraan (welfare economic approach).

Pemerintahan yang baik ditinjau dari sudut ekonomi harus memperhatikan efisiensi sehingga hukum benar-benar sebagai sarana untuk menciptakan kesejahteraan. Gary Goodpaster menjelaskan bahwa:

The choice of all the institutional frame work for an economy and society has a great impacts on personal incentives, the development of institutions intermediate between the state and citizens, and an economy's efficiency and growth. Effective law creates structures of expectation that guide official behavior and citizens can learn and use to make decisions and guide their own activities. ${ }^{+2}$

Indonesia mengalami krisis finansial karena membangun tanpa mendasarkan pada aturan hukum (rule of law) dan prilaku yang berdasarkan hukum (rule base behavior), padahal dalam politik ekonomi modern, rule of law adalah faktor yang menentukan. Indonesia mengalami kesulitan ekonomi yang dikarenakan ketidakmampuan mengatur dan memfungsikan secara efektif dalam kontek ekonomi global dan tidak mampu melanjutkan pertumbuhan ekonomi yang kuat tanpa landasan rule of law dan rule based behaviour. Disamping itu, pemerintah dituntut kemampuannya untuk mengkordinasikan kompleksitas pengaturan berbagai aturan yang didasarkan pengoperasian pasar untuk membuat keputusan yang tepat dan efisien. ${ }^{43}$ Tidak dapat disangkal, bahwa masyarakat yang mempunyai kebebasan ekonomi yang besar tidak menciptakan ketidaksamaan, karena terjadi redistribusi pendapatan yang menyebar ke tangan kelas menengah. ${ }^{44}$

Menurut Luhmann, bahwa hukum modern memfasilitasi kegiatan bisnis, ekonomi dan kegiatan lainnya dengan melalui penciptaan struktur yang terukur (calculable structure) dari suatu ekspektasi, sehingga hukum mampu memerankan sebagai "conditional programming" yang secara normatif dapat dikatakan bahwa jika kondisi tertentu terpenuhi maka

42 Gary Goodpaster, "The Rule of Law, Economic Development \& Indonesia", dalam Timothy Lindsey, "Indonesia (Law and Socciety)", (The Federation Press, Sydney, 1999), hal. 451.

${ }^{43}$ Ibid

44 Gerald W. Scully, "Constitutional Environments and Economic Growth", (Princeton: Princenton University Press, 1992), hal. 188-194. 
konsekuensi tertentu akan mengikuti dan menciptakan suatu conditional programming harus memenuhi persyaratan sebagai berikut: ${ }^{45}$

Pertama, hukum harus diketahui dan secara reasonable jelas sehingga pars aktor akan mengetahui kosekuensi yang ditimbulkan, selain itu hukum harus cukup jelas untuk menginformasikan pesan pada intellegent people, baik dengan sendirinya maupun dengan bantuan lawyer tentang apa yang diharuskan menurut hukum. Kedua, harus adanya akses secara bebas dan fair terhadap informasi sehingga terciptanya transparansi, dan ketiga, pembuat keputusan dalam hal ini pemerintah harus mentaati aturan dan menegakkannya. Berdasarkan elemen-elemen di atas, bahwa pembangunan hukum yang mempunyai level tinggi harus mengandung hal-hal berikut ini:

Clear, known laws, widespread information concerning what ever it is the law treats; decision-makers-accountability for, independence form, decisions results-comprises predictability and form of the foundation for rule-based behavior throughout society. ${ }^{46}$

Apabila telah tercapainya elemen-elemen hukum di atas, secara ekonomi, fakta telah membuktikan bahwa masyarakat yang berdasarkan rule of law lebih efisien daripada berdasarkan tradisi atau patronage based system, dan di Indonesia, hukum masih bersifat personalised dan patronage based. ${ }^{47}$ Berikut ini secara skematik, pengadaan barang dan jasa pemrintah mampu menciptakan tiga pengaruh yaitu pengaruh langsung, pengaruh ekonomi dan pengaruh sosial.

${ }^{45}$ Luhman, Niklas, "A Sociological Theory of Law", trans Elizabeth King and Martin Albrow (ed). Martin Albrow, (London: Routledege \& Kegan Paul, 1985), hal. 184.

\footnotetext{
${ }^{46}$ Ibid.

${ }^{47}$ Ibid.
} 


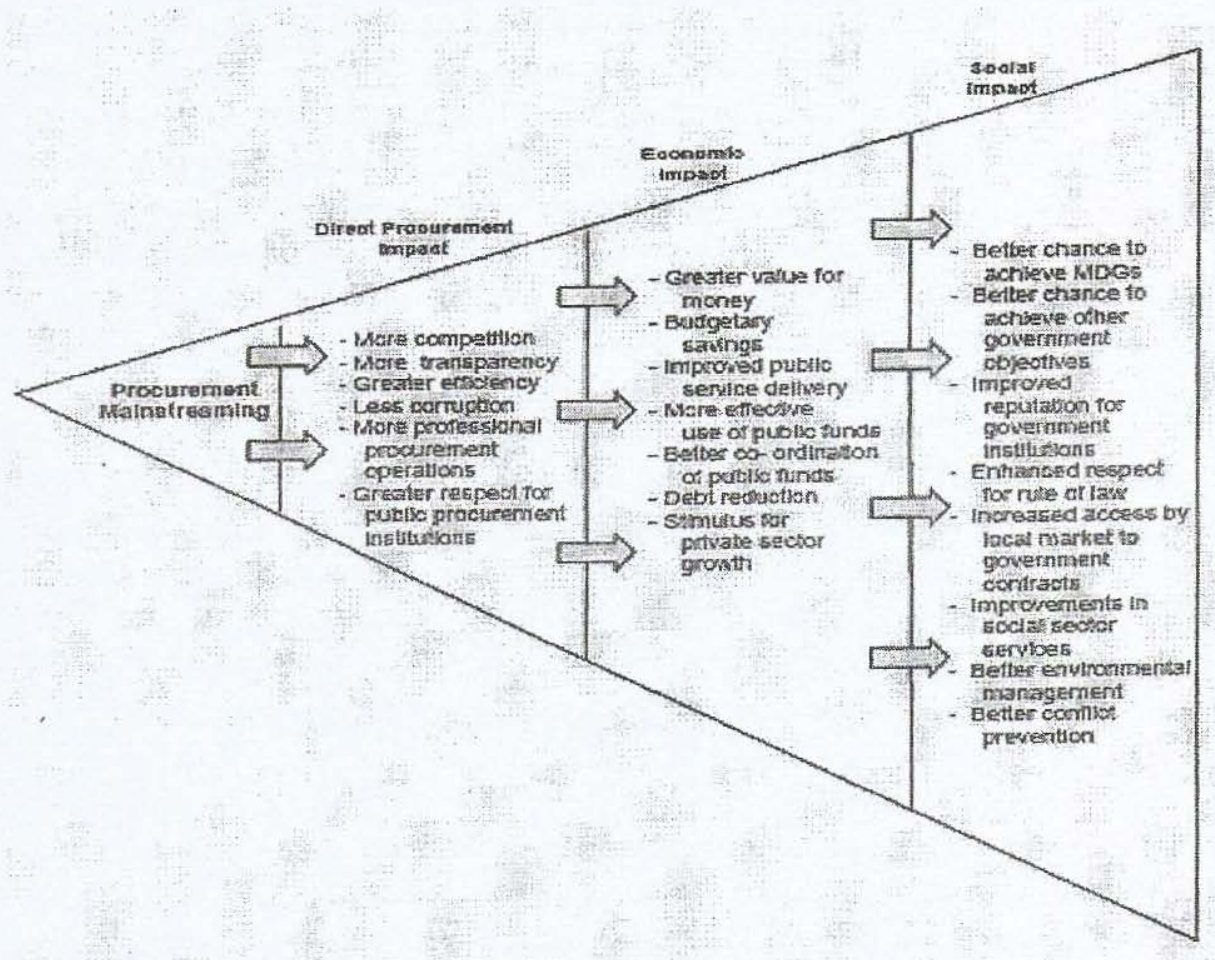

\section{Penutup}

Regulasi pengadaan barang dan jasa benar-benar mempunyai peranan yang penting dan strategis sebagai instrumen untuk pembangunan ekonomi dan pemerataan kesejahteraan. Di serjumlah Negara Eropa, dan beberapa Negara maju lainnya, pengaturan pengadaan barang dan jasa pemerintah menjadi bagian tidak terpisahkan dari kebijakan perdagangan, kebijakan kompetisi, kebijakan pemerataan kesejahteraan masyarakat dan keberpihakan terhadap sector usaha kecil dengan melibatkan Small medium enterprises seluas-luasnya. Dengan memperhatikan alasan-alasan dan oriantasi di bidang perekonomian, maka pengadaan barang dan jasa pemerintah dapat dijakdikan sarana untuk pembangunan masyarakat seluas-luasnya. Dengan memformulasikan undang-undang pengadaan barang dan jasa pemerintah yang efektif dan defisien maka akaqn mempunyai sejumlah dampak positif baik secara langsung maupun tidak langsung yang dapat dinikmati baik oleh masyarakat, pelaku usaha maupun pemerintah. Masyarakat dapat diuntungkan dengan semakin banyaknya pilihan dengan harga barang yang 
serendah-rendahnya namun dengan kualitas barang yang dapat dipertanggungjawabkan, sedangkan bagi pemerintah akan mampu meningkatkan citra pejabat publik dan mampu meningkatkan kepercayaan pembayar pajak sebagai sumber pembelanjaan pemerintah, sedangkan manfaat bagi pelaku usaha, dengan regulasi pengadaan barang dan jasa pemerintah yang transparan dan nondiskriminasi mampu menciptakan kepastian hukum dan iklim untuk berusaha secara transparan, kompetitif dengan memperhatikan prinsip-prinsip keadilan. 


\section{Daftar Pustaka}

\section{A. Buku}

Bakker, Anton, dan Achmad Charis Zubair. Metode Penelitian Filsafat, Yogyakarta: Kanisius, 1990.

BBC News. Free Trade Argument, Statistik Mengenai Keuntungan "Free Trade" sejak Perang Dunia ke II.

Croome, John. Guide to the Uruguay Round Agreement, 1999.

Goodpaster, Gary. The Rule of Law, Economic Development \& Indonesia, dalam Timothy Lindsey, Indonesia (Law and Society), Sydney: The Federation Press, 1999.

Grossfeld, Bernhard. The Strength and The Weakness of Comparative Law, Translated to English by Tonny Weir, Oxford: Clarendon Press, 1990.

Luhman, Niklas, A Sociological Theory of Law, Elizabeth King and Martin Albrow (ed)., London: Martin Albrow, Routledege \& Kegan Paul, 1985 .

Lyod's, MDA Freeman. Introduction to Jurisprudence, London: Maxwell, Ltd., 2001.

Mercuro, Nicolas, and Steven G. Medema. Economic and The Law, From Postner to Post Modernism, Priceton University Press, 1999.

Scully, Gerald W. Constitutional Environments and Economic Growth, Princeton University Press, Princeton, 1992.

Soekanto, Soerjono, dan Sri Mamudji. Penelitian Hukum Normatif: Suatu Tinjauan Singkat, Jakarta: Rajawali Press, 2004.

Sugema, Iman. "Anggaran Tidak Memberi Ruang Untuk Menstimulasi Pertumbuhan Ekonomi", INDEF, 2006.

Pangestu, Mari. Trade Reform, Deregulation and Competition Policy From an Indonesian Perspective, Frame Work For The twenty First Century, Economic Conference, USAID - LPEM FEUI,1997.

Posner, Richard A. Economic Analysis of Law, $5^{\text {th }}$ Edition, Aspen Law \& Business, 1997. . The Economics of Justice, Harvard: Harvard University Press, 
Radcliffe. Lord The Law and its Compas, 1961.

Ricardo. Principles of Political Economy and Taxation, 1817, dalam J.M. Dents \& Sons Ltd, Everyman's Library, 1978.

Spero, Joan Edelman. The Politics of International Economic Rclations, $3^{\text {rd }}$ edition, New York, 1985.

Sukirno, Sadono. Pengantar Teori Ekonomi Mikro, Lembaga Penerbit Fakultas Ekonomi Universitas Indonesia, 1985.

Trebilcock, Michael J. "Law and Economics", The Dalhouse Law Journal, Vol.16, No. 2, Fall, 1993: 361-363.

Wardhana, Ali. Sustaining Economic Growth in Indonesia, Frame Work For The twenty First Century, Economic Conference, USAID - LPEM FEUI, 1997.

World Trade Organization, Government Procurement: The Plurilateral Agreement Overview of the Agreement of Government Procurement, 2005.

WTO, World Trade Report, 2007.

\section{B. Jurnal}

Alessandrini, Donatella. "WTO And Current Trade Debate: An Enquiry Into The Intellectual Origins Of Free Trade Thought", International Trade Law \& Regulation Int. Trade. Law Review, 2005, 11(2): 53-60.

Berman, Harold J. Woodruff. "Justice versus Efficiency", Emory University School of Law, Washington Law Review, 2005: 70.

Carrier, Paul J. "Sovereignty Under The Agreement On Government Procurement", Minnesota Journal of Global Trade, Winter 1997: 85.

Dischendorfer, Martin. "The Existence And Development Of Multilateral Rules On Government Procurement Under The Framework Of The WTO", Public Procurement Law Review, Article Copyright (c) 2000 Sweet \& Maxwell Limited and Contributors, 2000: 543.

Gracia, Frank J. "Trade And Justice: Linking The Trade Linkage Debates", University of Pennsylvania Journal of International Economic Law, 1998: 391.

White, James Boyd. "Economics and Law: Two Cultures in Tension", 54 Tennesse. Law Review, 1987: 161, 198. 
Zwygert, Michael I., and Katherine Earle Yanes. "A Unified Theory of Justice The Integration of Fairness into Efficiency", Washington Law Review, April 1998: 249.

dan Katherin Earle Yanes. "A Unified Theory of Justice: The Integration Of Fairness Into Efficiency", Washington Law Review, April, 1998: I.

\section{Internet}

<www.wto.org>, "Laporan Hasil Pertemuan Tingkat Menteri", Pada Singapore Meeting, yang diselenggarakankan di Singapura pads tanggal 9-13 Desember 1996, dilanjutkan di Jenewa pads tanggal 1820 Mei 1998; Seattle (AS), 30 November sampai 3 Desember 1999, Doha (Qatar),10-14 November 2001; dan di Cancun Meksiko pads tanggal 10-14 September 2003, dan di Hongkong pada tahun 2006.

Cooter, Robert, \& Herman Selvin, "The Influence of Justice and Efficiency in The Economic Analysis of Law", Desember, 2003.h.2. dalam <www.berkeley.edu>, diakses pada tanggal 16 Desember Tabun 2007.

\section{Peraturan}

Direktur Jenderal Perbendaharaan Departemen Keuangan RI, 2006, Laporan Sementara Realisasi APBN Tahun Anggaran 2005, Periode 1 Januari 2005 sampai dengan 30 Desember 2005.

Keppres 80 Tahun 2003 yang telah diubah menjadi Perpres RI Nomor 8 Tahun 2006. 